\title{
Labour History
}

L'histoire ouvrière

Iorwerth Prothero

\section{(2) OpenEdition}

\section{Journals}

Electronic version

URL: http://journals.openedition.org/rfcb/6078

DOI: $10.4000 /$ rfcb.6078

ISSN: 2429-4373

\section{Publisher}

CRECIB - Centre de recherche et d'études en civilisation britannique

\section{Printed version}

Date of publication: 1 April 2008

Number of pages: 129-143

ISSN: 0248-9015

\section{Electronic reference}

Iorwerth Prothero, «Labour History », Revue Française de Civilisation Britannique [Online], XIV-4 | 2008,

Online since 01 April 2008, connection on 20 September 2020. URL : http://journals.openedition.org/ rfcb/6078; DOI : https://doi.org/10.4000/rfcb.6078

This text was automatically generated on 20 September 2020 .

\section{(c) $\oplus \Theta \Theta$}

Revue française de civilisation britannique est mis à disposition selon les termes de la licence Creative Commons Attribution - Pas d'Utilisation Commerciale - Pas de Modification 4.0 International. 


\title{
Labour History
}

\author{
L'histoire ouvrière
}

Iorwerth Prothero

1 Because Britain was the pioneer in industrialisation, development of a working class and formation of trade unions and workers' political organizations, these have always been of historical interest, but it was only in the second half of the twentieth century that labour history became a significant element in historical enquiry and in academia. Before then history in the universities was overwhelmingly focused on politics and had little interest in ordinary and working people or their organizations. Such concerns were merely a minority element in economic history, which rejected earlier views on the suddenness, severity and cataclysmic nature of the Industrial Revolution. Chartism was consequently seen as the protest against poverty by suffering groups of workers in a period of temporary economic difficulties until economic progress, liberal politics and social legislation took the edge off discontent and trade unions learned to use accommodation instead of confrontation to make gains.

2 Teachers and students following interests in the history of the working class and their movements were to be found mainly in various forms of adult education, such as the Workers' Educational Association, university extra-mural departments and trade union colleges, but the published work available to them was limited and often old. The massively researched history of British trade unions by the Fabian Socialists Sidney and Beatrice Webb ${ }^{1}$ remained the standard work for eighty years after it appeared in 1894, and even when a new survey appeared in the 1960s, it was intended as a continuation of their book. ${ }^{2}$ Labour history was written mostly by journalists, officials and activists rather than professional historians, often in political not academic publications. Such works tended to be on individuals and institutions, often reflecting initiatives from the main institutions of the labour movement, such as in centenary histories of local cooperative societies and official histories of trade unions, often by officers or ex-officers. A number of these were of limited scope and even antiquarian, although by the 1950s a number were commissioned for professional economic historians. ${ }^{3}$ The dominant themes in this history were the rise of trade unionism and of the Labour Party, both seen as progressive developments in the forward march of labour. Practitioners of 
labour history tended to see it as an aspect of political education, and they did not readily accept the academic view of labour history as consensual. A number were members of the Communist Party, which made them even less likely to gain permanent university employment.

The outstanding figure in labour history in the 1950s was Cole, who published extensively on a wide range of topics generally seen as constituting labour history workers' political movements, trade unionism, co-operation, and radical and social-ist ideas. ${ }^{4}$ Unusually a fellow at Oxford, he inspired generations of undergraduates, some of whom gained university posts and, equally importantly, he brought labour history to a wider reading public.

Before the 1960s, then, the academic study of labour history in Britain was far less developed than on the continent or in America and Japan. However by then some people who had made names for themselves as labour historians had university posts. Pelling at Oxford produced a well received book on the formation of the Labour Party ${ }^{5}$. Briggs at Leeds had revived interest in Chartism ${ }^{6}$. Others were Pollard at Sheffield, Hobsbawm at Birkbeck College in London (which taught students in the evening) and Saville at Hull. In 1954 Saville edited a collection of essays by Marxist historians ${ }^{7}$, and after Cole's death in 1959 Saville and Briggs edited a collection of essays in his honour. ${ }^{8}$ of the seventeen chapters in these two volumes on labour history, only nine were by British university teachers. Briggs, Hobsbawm, Saville, Pollard and Pelling were leading lights, alongside a number of adult education teachers, in forming the Society for the Study of Labour History (SSLH). The twice-yearly conferences were attended by a mixture of teachers, students, and veteran and current activists, for the society was not founded as an exclusively academic body and was always open to anyone who expressed an interest in the history of labour and wished to promote its understanding. It issued a publication, cyclostyled, not printed, in the form of a working bulletin, with bibliographies of works relating to labour history, information on work in progress and archive sources, reviews, letters, notes and queries, but no formal academic articles. ${ }^{9}$ The support of people not employed in "the academy" was a considerable encouragement to the academic members, who encountered hostility from some colleagues. They contributed to discussions at the conferences and several developed reputations for expertise in specific areas and made a notable contribution to the literature. In Manchester two Communist activists, Edmund and Ruth Frow, spent their lives amassing an extraordinary collection of materials which made their house and its 10,000 volumes a legendary magnet for researchers from home and abroad. ${ }^{10}$

5 This new institutional expression and focus was of crucial importance in the establishment of the notion of labour history, and proved well-timed for significant growth in the 1960s. The considerable expansion of the British university sector, including formation of new universities, meant a growth in the number of history posts, and researchers in labour history, including veteran adult education teachers, now had the chance of posts that would have been unavailable a few years before. University teaching and library holdings thus saw an expansion in labour history. Historical study of radicalism, and the radicalism of some of the labour historians, were more acceptable in the 1960s. Student interest and often involvement in radicalism led to a receptiveness to and demand for courses on past protest, radicalism, socialism and conflict. New works on these fields appeared as publishers quickly responded. 
6 As the expansion of history and historians in higher education grew, there were opportunities for new kinds and fields of history to flourish and the scope of history broadened beyond high politics. The main beneficiary of this was social history, which ceased to be a minor branch of economic history and became a current of great significance, transforming historical studies in Britain by looking at all levels in society, especially the humblest, and studying whole populations and societies. The process also involved more interest in sociology, which had hitherto hardly existed as an academic discipline but now rapidly spread out from the London School of Economics to the other universities, new and old, and became a fashionable, growing discipline. In contrast to the situation in America, British sociology, as it challenged intellectual and academic establishments, had a left-wing orientation and concern with improving society. One interest was in the question of the disappearance of the traditional working class and appearance of a new working class, which usually involved an historical dimension. ${ }^{11}$ Social historians and socio-logists were usually sympathetic to labour history, and this assisted its expansion as a branch of social history.

7 In the process labour history underwent change and also ceased to be a minor branch of economic history. Much of the new work was, as before, on individuals and organizations, and studies of the Labour Party were often extensions of familiar kinds of political history. But as history changed, instead of focusing on labour leaders, organizations and writers, there was an effort to get beyond these and understand the rank and file, ordinary people, in a form of social history. An earlier popular account of the British labour movement by Cole and his brother-in-law was entitled The Common People, ${ }^{12}$ but it was increasingly recognised that the figures it dealt with, those who had prominent and leading roles, were very untypical and unusual minorities, "uncommon people" in fact, and more labour historians looked at social structure and stratification, the experience of ordinary working people, the structure of work, occupational relations and communities, showing a greater interest in sociology and social theory. The radicalism of many, though by no means all, labour historians could also predispose them to get beyond institutions, leaders and the Labour Party, and not to see the story as one of progress. The Labour Party could be seen as smothering socialism and trade unions as thwarting militancy and class struggle, and so they sought to rediscover and revive alternatives that had been lost on the way.

8 The process was exemplified and inspired by an outstanding and massive book that appeared in 1963, by Edward Thompson, on working-class movements and protest between 1792 and $1832 .{ }^{13}$ This had an enormous impact and played a key role in arousing interest in labour history. Well-written, polemical, committed, challenging, exciting and dramatic, by no means confining itself to formal organizations, looking at the experience of workers and stressing the importance of informal and spontaneous communal action and protest, it captured the imagination and spirit of the 1960s and had a huge sale, in hundreds of thousands, over the world. It also looked at insurrectionary groups seriously, and combated the entrenched, complacent, consensual, liberal assumptions that dominated British historiography, of political and economic progress and the inevitability and desirability of integrated, legal, Parliamentary action and aspiration. Although in many ways reviving earlier views on the Industrial Revolution in work that had been discredited by empirical conservative economic historians that he excoriated, Thompson came out of the Marxist tradition, and in 1956 he and Saville had led opposition in the Communist Party of Great Britain 
to the authoritarian leadership accused of complicity in Stalinism. This resulted in a substantial secession that led on to alternative Marxist currents, such as the New Left. Thompson was a leading figure in rejecting a rigid Marxism characterised by mode of production analysis, materialist reductionism, and understanding of classes as objective and fairly monolithic entities engaged in a fairly mechanical and determined process of class struggle. Nor did he accept the crude Marxism of those who explained protest in terms of material grievances. Instead he stressed the subjective aspects of class, especially class consciousness. He looked at popular values, religion, culture and communities, and thereby broadened the horizons of labour history. He himself had taught literature as well as history as an adult education tutor, and written a book on William Morris ${ }^{14}$, and as the Communist Party lost its dominance in British Marxism there was a liberating diversity in Marxist approaches and an increasing downplaying of materialism (conservative historians were more likely to explain labour protest in terms of poverty rather than values and ideas ${ }^{15}$ ) and stress on cultural factors, including interest in Gramsci's concept of hegemony. Thompson's book had very little on factory-workers, miners or other "modern" workers and dealt instead with workers in unmechanised trades, such as artisans, handloom weavers and stockingers. Thus the process in class formation he stressed was not proletarianisation but subjective factors of feelings and experience drawing on established values and beliefs, so that the story was not entirely a progressive one, and, in rejecting Marxist notions of false consciousness and correct ideological understandings, he refused to dismiss opposition to mechanisation as "backward-looking".

9 Thompson's book confirmed the importance and status of labour history, aroused great enthusiasm and hostility, and provoked much historical debate and criticism in all shades of the political spectrum. Although one aspect of his influence was a perhaps excessive interest in small groups of unsuccessful conspirators and the possibility of revolution in Britain, he gave great encouragement to work on labour organization, campaigning and protest, interest in class, and in newer fields such a ritual, education and millenarianism, and established the place of labour history in social history.

Predictably, most of the new work on labour history tended to focus on the later nineteenth and twentieth centuries, the age of mass trade unionism and permanent labour politics, for which there were abundant sources and which were issues of importance in the 1960s, when the Labour Party was in power. But Thompson's enormous influence arose from a book on the more exciting early decades of the nineteenth century, and thereafter he turned his attention to riots, conflicts, values and rituals in the eighteenth century and helped inspire the pioneering work that transformed understanding of that age. ${ }^{16}$ Since the two most prestigious and admired exponents of labour history, Thompson and Hobsbawm, looked especially at the later eighteenth and first half of the nineteenth centuries, there was much greater interest than ever before in these years. The intensity of work on the 1750-1850 period made British labour history less concentrated on the modern industrial age than elsewhere, but also reinforced assumptions in sociological theory of a fundamental change around 1800 , from traditional to modern or "pre-industrial" to industrial society. And this was compatible with ideas on the modernisation of protest associated with the American Charles Tilly. ${ }^{17}$

11 Although its practitioners were as capable of high levels of scholarship, rigour and objectivity as any other branch, the success of labour history should not be 
exaggerated. It remained a minority current in academic institutions, especially universities, where entrenched and powerful figures and interests regarded it as inferior. It could be suspect as politically committed and tainted with communism, as an aspect of social history that was despised as overtly concerned with the insignificant and powerless who had little impact on the course of history, and as interested in "soft" topics like religion, culture and mentalities. Nevertheless the 1960s were a good decade for labour history, when it came of age and established its presence in the historical world. Its practitioners felt themselves pioneers and trail-blazers, leading history where it had not been before, innovators breaking with the old concerns and preconceptions of established historians, and democratising history through getting at real, ordinary people, a process widely appreciated by students. Postgraduate research grew, the SSLH expanded and was imitated abroad, while in Britain local and regional labour history societies appeared, usually running their own journals, one of the most active the bilingual Welsh Labour History Society. This had strong links and sympathies with the South Wales miners, and most such societies grouped academic labour historians, teachers, non-academic practitioners, trade unionists, and officials, activists and veterans of the labour movement. They also worked to identify, collect, preserve, publicise and generally make accessible sources for labour history, and the SSLH pressed for the opening up of government document archives at the Public Records office. Trade unions had tended to be very bad at keeping their records, and when branches closed or merged all their documents were usually thrown away. Many of the trade union records used by the Webbs in their trade union history have not survived, and consequently their notes on them, held at the London School of Economics, remain a historical source. The Modern Records Centre at the University of Warwick now gathered extensive business and trade union records which were thereby saved for researchers. Local museums were encouraged to value, catalogue, microfilm and publicise labour records more. A small museum collection of labour records and artefacts in London was relocated to Manchester where, under Nick Mansfield and with financial support from local Labour Party-controlled councils, it flourished as the National Museum of Labour History, building up and restoring archives and artefacts, particularly trade union banners, and arranging a regular series of exhibitions.

12 Yet despite this progress in labour history, there were elements of unease. Although most labour historians were in some way on the left politically, there were differences over how their history should reflect and express commitment and form part of a wider enterprise (from its origins the SSLH took pains to emphasise it was not politically aligned in any way). There were tensions between academics and non-academics, over what seemed crude and ill-informed views on working-class oppression and solidarity, or caution over conclusions, commitment to impartiality and accuracy, and emphases on careful and extensive research and proper referencing of statements. Nonacademics might feel bashful before academics, and ill at ease with their new, complicated ideas, while activists did not always welcome the resurrection of old differences, discrediting of old heroes and reinterpretation of past episodes, in which some had themselves been involved. There was some unease at the phenomenon of professional, middle-class historians studying poor, suffering and insecure past workers. The spread of labour history in institutions of higher education might be seen as robbing workers of their history, turning it into fodder for academic historians to make their careers, as part of that increasing professionalisation of history whereby historians increasingly wrote for one another instead of to the world at large or the 
sort of people they made their living from, and, in the words of the illustrious historian and founder-member of the SSLH, Tawney, "make a darkness and call it research", so that the impact and role of history shrank in the modern world.

The most effective exponent of this idea was Raphael Samuel, a tutor at Ruskin College in Oxford which was loosely attached to the university there. It was one of several residential colleges founded in different parts of the country earlier in the century to enable able workmen to participate in a higher level at education than was normally available to them. Students who had for various reasons missed out in their schooling and thus been deprived of the chance of pursuing it further could take courses there for a year or two and gain a diploma, although increasingly these colleges served to prepare such people for entry into higher education. At Ruskin Samuel particularly inspired a number of workingmen and trade unionists to follow up their own history and research their own trade, occupation or community. He then started to organise informal conferences called "history workshops", bringing together academic historians, Ruskin students and members of the wider public in common historical interests and discussions. The organisation and procedures were informal and inexpensive, those attending bringing their own sleeping-bags and sleeping on floors. The gatherings were often enjoyable and uplifting, and led to the foundation of a journal, History Workshop, to serve all kinds of historians, professional and otherwise, in a democratic, non-elitist enterprise that would help any one to become a historian and make his/her own history. History was part of a wider political project, too important to be left to the historians, and the journal bore the sub-title "a journal of socialist historians". The enterprise was called "people's history" an older term preferred to labour history, which might imply a restriction in scope, although labour history was always a history workshop concern.

The enterprise generated much interest and enthusiasm, local history workshop groups came into being and new opportunities to follow history were opened up, although the project did not gain unanimous approval. A new professionally organised Social History Society was on a different plane and looked askance at the sleeping-bag brigade. It was soon followed by a new successful academic journal, Social History. Many others, while agreeing that history should reach a wider audience, doubted that everyone could do history, a discipline which, if it went beyond the superficial, anecdotal and naïvely enthusiastic, required the learning of qualities and rigour and was thus ipso facto elitist, even if it looked at ordinary people. While the movement undoubtedly did involve new people in new kinds of historical practice, the extent to which the boundaries were really extended to new classes, even in the readership of History Workshop, was not clear.

15 A prime divisive issue in local labour history and history workshop groups proved to be theory. Many amateurs seemed uncritical and undiscriminating in their admiration for past figures and movements, and too concerned with celebration rather than social theory. Their writings might be praised as inspirations to activists but criticised as untheoretical. There were also always pressures in higher education to make any discipline more theoretical, but such work could seem extremely abstract, unattractive, alienating and pointless to many of those seeking to satisfy a part-time interest in past labour movements. History Workshop began to publish theoretical articles illustrative of the new modish interest in structuralism, and while this provoked a debate among academics, many felt shut out and the move aroused controversy and opposition. In 
fact disputes at Ruskin and in history workshops groups were divisive and disrupted the project of a common enterprise. In the long run the great expansion of the university sector and access to it meant a remorseless professionalisation of history and the decline of extra-mural courses, the WEA and the respected part-time amateur.

Thus the labour history that rose to prominence in the 1960s contained various strands - an interest in the traditional topics of labour history, a desire that this branch of history be accepted in the academic world as equal in scholarship and importance to any other, an extension of the boundaries of historical enquiry to include the humble masses of the population, and a broadening of the historical community to enable ordinary people to discover their own history. Although the radical impetus of the 1960s waned in subsequent decades, and university radicalism was increasingly to be found among (ex-radical student) lecturers rather than students, the work continued and student interest remained strong enough.

17 A big change came in the 1980s, a bad decade for the left. The ascendancy of the Conservative Party from 1979 to 1997, the enthusiasm over the Falklands War, the defeat of the miners' strike and decline of trade unionism, the Thatcherite revolution and the cuts in higher education funding all had far-reaching effects. Radicalism declined, and the optimistic sense of the forward march of labour was shattered. In this situation much of the incentive for interest in or enthusiasm for labour history was removed. Not only did radicalism decline, but radicalism also changed and became less interested in the history of a labour movement that had always been confined to a minority of the population. There was now a new interest in other minorities and divisions of race, gender, and sexuality. Thus the previously much-admired Chartists were now seen as exclusively seeking political rights for men alone and assuming male ascendancy, and those of them who emigrated to the colonies and America often proved racist in their attitudes to native peoples. Especially important here was the history of women. A pioneer was the labour historian Sheila Rowbotham, ${ }^{18}$ and many proponents of women's history saw workers and women as alike oppressed and engaged in common or complementary struggle, and labour history come to incorporate the study of women. ${ }^{19}$ The History Workshop subtitle became "a journal of socialist and feminist historians" - there were bets on when gay liberation would be added. But as the genre developed more and more did not share this view and stressed the subordination and oppression of women in working-class communities and labour organizations. The radicalism of past movements which excluded females was questioned, labour history being another example of the study of dead white males.

Interest in the displacement of the Liberal party by Labour in the early twentieth century has always remained, and led to a wide range of forms of historical study changes in industrial structure and workforce, growth of socially differentiated suburban communities, extension of trade unionism to unskilled workers, attitude to trade unions by employers, judiciary and the state, changes in electoral systems and local and national voting behaviour, developments in the Liberal Party, local and Parliamentary politics, the effects of the First World War. One product of anti-Thatcher projects was a greater stress on the common ground not only between the Liberal and Labour parties in the twentieth century but also between liberalism and working-class radicalism in the nineteenth..$^{20}$ One historiographical debate among labour historians has always concerned the early emergence of Chartism, its demise in mid-century before a Liberal ascendancy, followed in the last two decades by the rise of independent 
labour political organizations culminating in the Labour Party. Since the Liberal ascendancy after 1850 was widely attributed to cultural elements, particularly Nonconformist religion, some of those rejecting the anti-Thatcher perspective tended to focus on alternative cultural movements, ${ }^{21}$ and this was part of a greater focus in labour history on popular culture..$^{22}$

Labour history had, ever since Thompson's book, included an interest in culture, and the end of the Communist Party's ascendancy in British Marxism encouraged Marxist studies that were far less materially based. The change is illustrated in debates on the emergence of a "labour aristocracy," which Hobsbawm had identified in the decades after 1850 as the chief reason for the demise of Chartism and rise of moderate liberallabour politics and craft "new model" trade unionism. Whereas initially the explanation of this moderation had been "economist", that these workers were better off and more secure, the emphasis shifted over time to emphases on work divisions and social differentiation, and finally to way of life and culture. ${ }^{23}$

Thompson's location of working-class formation in the 1830s had always been challenged, and many preferred a more traditional stress on modern workers, especially factory workers and miners, and on the 1880-1920 period, among them Marxists such as Hobsbawm. ${ }^{24}$ Not all Marxists had followed Thompson's stress on class consciousness, although fewer few espoused a Leninist alternative. ${ }^{25}$. His book had little on labour disputes or class struggle and concentrated mainly on political radicalism and the currents that fed it. Its climax in 1832 only made sense because Chartism lay a few years in the future, and in many ways his book was about the sources of Chartism. Since Thompson saw political oppression as the chief element in his story, the selfdefinition of those he studied was likely to be as much political as economic, and it seemed that it was political, not economic grievances that fuelled this radicalism and underlay the categories it used. ${ }^{26} \mathrm{~A}$ stress on class consciousness easily led to obsession with class terminology and the use of the words "class", "working class" and "middle class". ${ }^{27}$ It was an easy mistake to assume that all uses of class terminology were the same as each other and also meant the same as they do today. A focus on class language also meant that class consciousness did not exist before the nineteenth century. ${ }^{28} \mathrm{But}$ it seemed that class terminology was not consistent or dominant, and that "working class", "people", "producers" and "artisans" were used interchangeably in an imprecise way. This, together with the prominence of artisans ${ }^{29}$ and the socially mixed composition of the early radical movements Thompson dealt with led to a preference for the more ambiguous terms "popular" or "plebeian" radicalism, and for some this facilitated an emphasis on continuities between the two halves of the century in a shared populism. ${ }^{30}$

21 Marxists associated with the New Left lamented the weakness of the British labour movement because it lacked a proper socialist ideology, and felt Thompson had not sufficiently recognised that Britain was capitalist long before the nineteenth century, and some were interested in what Marx had said about the age of manufacture and formal and real subsumption of labour. The work of Braverman stimulated work on the labour process, division of labour, and workplace conflicts and authority, often downplaying the importance of formal trade union organization. ${ }^{31}$ Indeed, it could result in union officials and leaders' being seen as predisposed to securing union recognition and maintaining secure negotiating positions through compromise, and thus checking militancy, an approach that became known as "rank and fileism". For 
many, this explained the nature of labour politics, but because class struggle against insecurity could divide and fragment the working class, and lead to trade particularism, craft unionism based on exclusion of other workers, and even racism and nationalism, it could imply the permanent absence of class consciousness and unity. Studies of the workplace led to a growing feeling that explanations of labour politics founded on a labour aristocracy did not work, and encouraged the conclusion that politics did not directly reflect the economic base and could not be read off from the workplace, in an assertion of the autonomy of politics.

Some of the New Left were attracted by structuralism and the writings of Althusser, which Thompson attacked as akin to Stalinism as a closed ideological system impeding proper enquiry. ${ }^{32} \mathrm{~A}$ leading figure in the New Left, Gareth Stedman Jones combined some of these strands in an article on Chartism ${ }^{33}$. The Briggs volume of Chartist studies inspired a twenty-year long cottage industry of isolated local studies on Chartism, which often lost all sense of the national dimensions of the movement. There had therefore been renewed interest in radical organization, strategy and ideas. ${ }^{34}$ Stedman Jones' article did not see Chartism as a class movement but one that used an inherited radicalism and was thus almost imprisoned in a pre-Marxist ideology that inhibited a proper class awareness. Although this was essentially a study of radical ideas, it was organised as an argument on the importance of language. Rather than people having feelings and thoughts and then finding the language to express them, it is the case that people think in language, and their language thus directs and limits what they can think. This article had a big impact and provoked the "linguistic turn" in social history. 35

All these currents led labour history to share in two developments that became widespread in history generally. One was to deny that the socio-economic sphere was in any way more basic than any others; even if it helped provide constituencies of support for movements and ideas, other spheres should not be seen as dependent on it. This could lead to very traditional history that treated politics and ideas almost in isolation. The second, more radical development, found across the whole field of humanities and social sciences, was the growth of interest in linguistic theory, poststructuralism and deconstruction and admiration for a number of French philosophers, such as Saussure, Derrida and especially Foucault. Feminist history, for instance, was particularly innovative as it moved into gender study, examining what it was to be a woman or man. There were divisions in this tendency, especially between those who saw language as a set of rules, channelling, restricting or directing thought, and those seeing it as a set of resources to be used, including for resistance.

Thus social history increasingly became cultural history and leading historians who wrote on labour history embraced these new developments. ${ }^{36}$ The material base was denied, and categories such as skill were seen not as objective givens but as subjective creations. ${ }^{37}$ Trade unions were not the inevitable outcomes of the structure of work but were constructions imposed on the workforce, and artisan pride in their trade was an artificial construction..$^{38}$. The division of labour was culturally determined..$^{39}$ Class was not seen as basic but as merely one identity among several. The stress on how identities were constructed, or imagined, not given, meant a stress on culture and language, ${ }^{40}$ indeed some felt that language was now being reified as a basic determinant.

The main expression of or epithet for of these tendencies was in the vague and very contentious term "post-modernism". ${ }^{41}$ Its distaste for grand narratives and self- 
legitimising theories, notably Marxism, as leading to intellectual sterility and oppression, and its distrust of any claim that knowledge, language and categories derived from them, notably class, were not subjective and relative, was seen as an affront that affected social history and was perhaps seen particularly as a threat to labour history as it opposed the traditional concern of social history with socioeconomic foundations. Labour history was open to attack for excluding women, focusing on activists instead of the working population generally, offering a chronicle of modernity in a whig history of industrial society, socialism and social-democratic reformism, and having as its main unifying element some sort of conception of a working class.

Thus in the mid-1990s British labour history continued to suffer from the discrediting of socialism, shortage of private and public research funding, and a reputation for being too institutionally based, Eurocentric, concerned with male workers and verging on antiquarianism. It seemed ill-placed in a discipline embracing the history of the body and subaltern and post-colonial studies. Labour history, like history generally in Britain, had in fact always been insular, little affected by historical developments abroad, or showing much awareness of imperialism and the effect of the empire on Britain. Few British labour historians studied foreign labour movements, although more recently this has changed in the shape of comparative studies, usually not involving research on activities elsewhere but reading secondary literature on, mainly, English-speaking countries. ${ }^{42}$

In fact during the second half of the century labour history undoubtedly changed, in size, reputation, scope and approach. Over those decades a number of theoretical approaches in turn informed its studies - Marxism, structural-functionalism, classconsciousness, social control, hegemony, structuralism, control of the labour process, autonomy of politics, linguistic turn, post-structuralism. Irritatingly, it was often the same people taking them up in turn. However, they were the concern of minorities, and we should not exaggerate their impact on most of the work on the established objects of labour history - the political, trade union, co-operative, educational and intellectual activities of working people - all of which remain the object of investigation. Biographies of Labour Party politicians and trade unionists continue to appear, as do studies of the Labour Party ${ }^{43}$ trade unions and strikes, Chartism, past radical and socialist movements and writings, popular protest, workplace relations and workingclass communities. Interest in and work on all of these continues, and there are established personal and institutional bases for it to do so in the future. The Museums, Libraries and Archives Council has awarded designated status to the archive at the London School of Economics, the People's History Museum in Manchester, the Modern Records Centre at the University of Warwick, and the Women's Library at the London Metropolitan University. The opening up of Communist Party archives led to a number of local studies of the Party. Moreover, like all branches of history, labour history has gained from the great expansion of information available and access to it, and more material available in digitalised form.

Thus in one sense labour history is stronger than ever. It is also becoming more inclusive and relevant to new generations ${ }^{44}$ But it is no longer seen as pioneering, trailblazing or innovative, and with the transformations of British society and politics, the changes in the industrial structure and labour force (including decline of manufacturing and virtual disappearance of coalminers), transformation of trade 
unionism, ascendancy of New Labour, and decline in university extra-mural and selfhelp education, the sense of a working-class movement has largely disappeared. For this reason the unifying bond between all the different work on labour history is far less clear, and labour history has been engaged in reinventing itself. The Bulletin of the Society for the Study of Labour History became a standard academic journal, the Labour History Review. History Workshop dropped its subtitle "journal of socialist and feminist historians". There are more fashionable fields to attract university support than something called "labour history" and the very term seems a liability, too restrictive, exclusive and politically partisan, and there has been a shift towards the History Workshop term "people's history". In 1987 the Welsh Labour History Society became the Welsh People's History Society/Cymdeithas Hanes Pobl Cymru. The North West Labour History Group was founded in 1973 and although it successfully involved a mixture of practitioners, its finances were often precarious and at one time a leading figure John Smethurst had to use his house as security for a bank loan to ensure the continuation of their bulletin. It is now a much stronger organization but is similarly currently considering changing its name. The National Museum of Labour History in Manchester was dependent on support from local Labour-controlled councils, and struggled to erase perceptions of it as politically aligned; indeed it organised an exhibition on working-class Toryism that was opened by the then leader of the Conservative Party, William Hague. As local government finances shrank its situation worsened, universities were not willing or able to support it, and the opening hours of its Labour History Study and Archives Centre were restricted. In 2005 it became the People's History Museum and has now at last secured financial security through National Lottery and regional development funding. In contrast, the magnificent Frow collection, which in 1987 moved to Salford University as the Working Class Movement Library, is now losing support from Salford City Council and in a precarious position, reduced to appealing for salvation to the labour movement. Thus the enduring constituents of labour history continue to be pursued, but its transmogrification into people's history reveals a changing perception of what and where it is.

\section{NOTES}

1. Sidney \& Beatrice WEBB, The History of Trade Unionism, London: Longman, 1894.

2. A.CLEGG, A.FOX \& A.F.THOMPSON, A History of British Trade Unions since 1889, Oxford: Clarendon Press, 1964).

3. E.g. A.E. MUSSON, The Typographical Association; origins and history up to 1949, Oxford: Oxford University Press, 1954; A. FOX, A History of the National Union of Boot and Shoe Operatives, Oxford: Blackwell, 1958; P.S. BAGWELL, The Railwaymen; the history of the National Union of Railwaymen, London: Allen \& Unwin, 1964.

4. E.g. G.D.H. COLE, British Working-Class Politics 1832-1914, London: Routledge, 1941; Chartist Portraits, London: Macmillan, 1941; A Century of Co-operation, London: Allen \& Unwin, 1944; Attempts at General Unionism; a study of British trade union history 1818-1834, London: Macmillan, 1953; A History of Socialist Thought, 5 vols., London: Macmillan, 1953-1960. 
5. H.M. PELLING, The Origins of the Labour Party 1880-1900, Basingstoke: Macmillan, 1954.

6. A. BRIGGS (ed.), Chartist Studies, London: Croom Helm, 1959.

7. J. SAVILLE (ed.), Democracy and the Labour Movement: essays in honour of Dona Torr, London: Lawrence \& Wishart, 1954.

8. A. BRIGGS and J. SAVILLE (eds.), Essays in Labour History, London: Macmillan, 1960. Two more such collections subsequently appeared: Essays in Labour History 1886-1923, London: Macmillan, 1971; Essays in Labour History 1918-1935, London: Macmillan, 1977.

9. Bulletin of the Society for the Study of Labour History.

10. E.g. E. \& R. FROW, 1868, Year of the Unions: a documentary survey, London: Katanka, 1968; Karl Marx in Manchester, Manchester: Manchester Free Press, 1986.

11. J.H. GOLDTHORPE \& D. LOCKWOOD, The Affluent Worker; industrial attitudes and behaviour, Cambridge: Cambridge University Press, 1968; The Affluent Worker; political attitudes and behaviour, Cambridge: Cambridge University Press, 1968; The Affluent Worker in the Class Structure, Cambridge: Cambridge University Press, 1969.

12. G.D.H. COLE \& R.W. POSTGATE, The Common People, 1746-1938, London: Methuen, 1938.

13. E.P. THOMPSON, The Making of the English Working Class, London: Gollancz, 1963.

14. E.P. THOMPSON, William Morris; romantic to revolutionary, London: Lawrence \& Wishart, 1955.

15. M. COWLING, The Impact of Labour, 1920-1924, Cambridge: Cambridge University Press, 1971.

16. E.P. THOMPSON, Customs in Common, Harmondsworth: Merlin, 1991; J. BREWER and J. STYLES (eds.), An Ungovernable People: the English and their law in the seventeenth and eighteenth centuries, London, 1980.: Hutchinson

17. C., L, \& R. TILLY, The Rebellious Century, Cambridge, Mass.: Harvard University Press, 1975); C. TILLY, Popular Contention in Great Britain, 1758-1834, Cambridge Mass. \& London: Harvard University Press, 1995).

18. S. ROWBOTHAM, Hidden from History: 300 years of women's oppression and the fight against it, London: Pluto Press, 1973.

19. E.g. A. JOHN, Coalmining Women; Victorian lives and campaigns, Cambridge: Cambridge University Press, 1984; id, Unequal Opportunities; women's employment in England 1800-1918, Oxford: Blackwell, 1986; id. (ed.), Our Mother's Land; chapters in Welsh women's history 1830-1939, Cardiff: University of Wales Press, 1991; A. JOHN and C. EUSTACE (eds.), The Men's Share? Masculinities, male support and women's suffrage in Britain, 1890-1920, London: Routledge, 1997.

20. E.F. BIAGINI \& A.J. REID (eds.), Currents of Radicalism; popular radicalism, organised labour and party politics in Britain, 1850-1914, Cambridge: Cambridge University Press, 1981.

21. S. SHIPLEY, Club Life and Socialism in mid-Victorian London, Oxford: Ruskin College History Workshop, 1971; L. BARROW, Independent Spirits; spiritualism and English plebeians 1850-1910, London: Routledge, 1986; I. McCALMAN, Radical Underworld; prophets, revolutionaries and pornographers in London, 1795-1840, Cambridge: Cambridge University Press, 1988; E.P. THOMPSON, Witness against the Beast. William Blake and the moral law, Cambridge: Cambridge University Press, 1993.

22. E. \& S. YEO (eds.), Popular Culture and Class Conflict 1590-1914, Brighton: Harvester, 1981; M. Chase, 'The People's Farm': English radical agrarianism, 1775-1840, Oxford: Clarendon Press, 1988.

23. E.J. HOBSBAWM, "The labour aristocracy in nineteenth-century Britain”, in SAVILLE (ed.), Democracyy and the Labour Movement, op. cit; G. CROSSICK, An Artisan elite in Victorian Society; Kentish London 1840-1880, London: Croom Helm, 1978; R. GRAY, The Labour aristocracy in Victorian Edinburgh, Oxford: Oxford University Press, 1976; id, The aristocracy of Labour in Nineteenth-Century Britain c1850-1900, London: Macmillan, 1981.

24. E.J. HOBSBAWM, "Custom, wages and work-load in nineteenth-century industry", in BRIGGS \& SAVILLE (eds.), Essays in Labour History, op. cit. (reprinted in Hobsbawm's Labouring Men); HOBSBAWM, Worlds of Labour: further studies in the history of labour, London: Weidenfeld \& Nicolson, 1984. 
25. J. FOSTER, Class Struggle and the Industrial Revolution; early capitalism in three English towns, London: Weidenfeld \& Nicolson, 1974.

26. I. PROTHERO, 'William Benbow and the concept of the "general strike", Past and Present no. 63 (1974).

27. A. BRIGGS, 'The language of "class" in early nineteenth century England,' in BRIGGS and SAVILLE (eds.), Essays in Labour History, op. cit..

28. E.J. HOBSBAWM, "Class consciousness in history", in I. MESZAROS (ed.), Aspects of History and Class Consciousness, London: Routledge, 1971; E.P. THOMPSON, “Eighteenth-century English society", in his Customs in Common, op. cit..

29. I. PROTHERO, Artisans and Politics in early Nineteenth-Century London. John Gast and his times, Folkestone: Dawson, 1979.

30. P. JOYCE, Visions of the People; industrial England and the question of class, 1848-1914, Cambridge: Cambridge University Press, 1991.

31. H. BRAVERMAN, Labour and Monopoly Capital; the degradation of work in the nineteenth century, New York \& London: Monthly Review Press, 1974; K. BURGESS, The Origins of British Industrial relations; the nineteenth-century experience, London: Croom Helm, 1975; id., The Challenge of Labour; shaping British society, 1850-1930, London: Croom Helm, 1980; R. PRICE, Masters, Unions and Men; work control in building and the rise of labour, Cambridge: Cambridge University Press, 1980; S. TOLLIDAY and J. ZEITLIN, Shop Floor Bargaining and the State; historical and comparative practices, Cambridge: Cambridge University Press, 1985; R. HARRISON and J. ZEITLIN (eds.), Divisions of Labour; skilled workers and technological change in nineteenth century England, Brighton: Harvester, 1985.

32. E.P. THOMPSON, The Poverty of Theory, and other essays, London: Merlin, 1978; P. ANDERSON, Arguments within English Marxism, London: Schocken, 1980.

33. G. STEDMAN JONES, Languages of Class; studies in English working-class history, 1832-1982, Cambridge: Cambridge University Press, 1983, chap.1.

34. J. EPSTEIN, The Lion of Freedom: Feargus O'Connor and the Chartist movement, 1832-1842, London: Routledge, 1982; J. BELCHEM, 'Henry Hunt and the evolution of the mass platform,' English Historical Review 93 (1978); id., 'Orator' Hunt; Henry Hunt and English working-class radicalism, Oxford: Oxford University Press, 1985; id., 'Republicanism, popular constitutionalism and the radical platform in early nineteenth-century England', Social History 6 (1981).

35. See especially debates in Social History.

36. W.H. SEWELL, Work and revolution in France: the language of labor from the Old regime to 1848, Cambridge: Cambridge University Press, 1980; J. SCOTT, The Glassworkers of Carmaux: French craftsmen and political action in a nineteenth-century city, Cambridge, Mass.: Harvard University Press, 1974; L. TILLY \& J. SCOTT, Women, Work and Family, London: Holt, Rinehart \& Winston, 1978; J. SCOTT, Gender and the Politics of History, New York \& Oxford: Columbia University Press, 1999; L. BERLANSTEIN (ed.), Rethinking Labor History: essays on discourse and class analysis, Urbana: University of Illinois Press, 1993.

37. C. MOORE, Skill and the English Working Class, 1870-1914, London: Croom Helm, 1980.

38. J. RANCIERE, "The myth of the artisan. Critical reflections on a category of social history", International Labor and Working Class History no. 24 (1983).

39. P. JOYCE (ed.), The Historical Meaning of Work, Cambridge: Cambridge University Press, 1987, introduction.

40. P. JOYCE, Democratic Subjects; the self and the social in nineteenth-century England, Cambridge: Cambridge University Press, 1994; J. VERNON, Politics and the People: a study in English political culture, c1815-1867, Cambridge: Cambridge University Press, 1993.

41. K. JENKINS, Rethinking History, London: Routledge, 1991; P. JOYCE, "The end of social history," Social History 20 (1995); id., "The return of history: postmodernism as the politics of academic history in Britain," Past and Present no. 158 (1998); J. HOST, Victorian Labour History: experience, identity and the politics of representation, London: Routledge, 1998. 
42. D. HOPKIN and G. KEALEY (eds.), Class, Community and the Labour Movement: Wales and Canada 1850-1930, Cardiff: Llafur, 1989; D. GEARY, European Labour Politics from 1900 to the depression, London: Macmillan, 1991; S. BERGER, The British Labour Party and the German Social Democrats 1900-1931, Oxford: Clarendon Press, 1994; J. BREUILLY, Labour and Liberalism in Nineteenth-Century Europe. Essays in comparative history, Manchester: Manchester University Press, 1992; N. KIRK, Labour and Society in Britain and the USA 1780-1939 2 vols. Aldershot: Scolar Press, 1994; R. FAGGE, Power, Culture and Conflict in the Coalfields: West Virginia and South Wales, 1900-22, Manchester: Manchester University Press, 1996; I. PROTHERO, Radical Artisans in England and France 1830-1870, Cambridge: Cambridge University Press, 1997.

43. e.g. S. FIELDING, The Labour Party: continuity and change in the making of New Labour, Basingstoke: Palgrave Macmillan, 2003; J.CALLAGHAN, S. FIELDING and S.LUDLAM (eds.), Interpreting the Labour Party: approaches to labour politics and history, Manchester: Manchester University Press, 2003; S. FIELDING, The Labour Governments 1964-1970 Manchester: Manchester University Press, 2003; L. BLACK, The Political Culture of the Left in Affluent Britain, 1951-1964, Old Labour, New Britain?, Basingstoke: Palgrave Macmillan, 2003; M. WORLEY, Labour inside the Gate: a history of the British Labour Party between the wars, London: I.B. Tauris, 2005.

44. S. BERGER (ed.), Labour and Social History in Great Britain: historiographical reviews and agendas, Mitteilungsblatt des Instituts für soziale Bewegungen, Klartext Verlag, 2002; L.H. van VOSS and M. van der LINDEN (eds.), Class and Other Identities: gender, religion and ethnicity in the writing of European Labour History, London: Berghahn Books, 2002.

\section{ABSTRACTS}

Interest in British labour movements since the Industrial Revolution has a long history in Britain, but it was only in the 1960s that labour history became a significant element in British university historical studies. This reflected the expansion and broadening of academic history, especially the growth of social history, and the political radicalism of that decade. It met some hostility because its practitioners saw themselves as pioneers challenging traditional history and often coupled their historical work with political commitment. Labour history was also allied with the History Workshop movement to broaden involvement in historical studies. Although it has continued to grow since then, it became less fashionable after the 1970s as politics shifted to the Right, labour organizations declined, and it lost its radical edge because of feminist and postmodernist critiques. The efforts to adapt are reflected in the displacement of the term "labour history" by "people's history".

Cela fait longtemps, en Grande-Bretagne, qu'on s'intéresse aux mouvements ouvriers depuis la révolution industrielle, mais c'est seulement dans les années 1960 que la labour history y a pris toute sa place dans les études historiques universitaires. Cela reflétait le développement de l'histoire universitaire et l'élargissement de ses champs, en particulier la place plus grande accordée à l'histoire sociale, ainsi que le radicalisme politique des années 1960. La labour history a rencontré une certaine hostilité parce que ses praticiens se voyaient comme des pionniers mettant en cause l'histoire traditionnelle et qu'ils couplaient souvent leur travail historique avec leur engagement politique. La labour history était également liée au mouvement du History Workshop visant à élargir la participation et l'implication dans les études historiques. Bien qu'elle ait continué à s'enrichir depuis, elle est cessé d'être à la mode après les années 1970, 
quand la vie politique a viré à droite, que les organisations ouvrières ont décliné, et elle a perdu son aspect radical à cause des critiques postmoderniste et féministe. Le passage de l'expression « labour history" (histoire ouvrière) à celui de "people's history» (histoire du peuple) reflète ce déplacement.

\section{AUTHOR}

\section{IORWERTH PROTHERO}

University of Manchester

School of Arts, Histories and Cultures, University of Manchester, Oxford Road, MANCHESTER, M13 9PL 